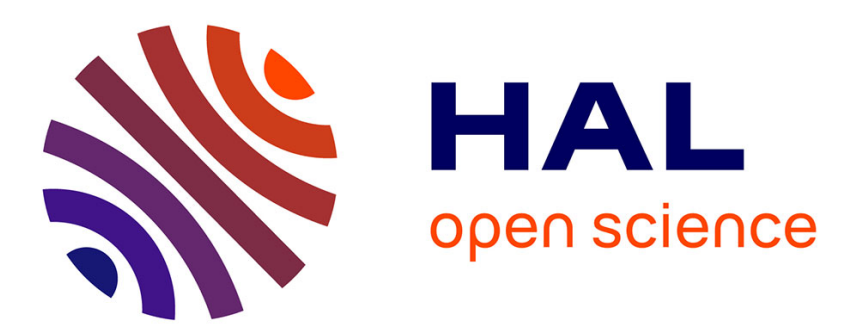

\title{
Cadmium, copper and zinc in octopuses from Kerguelen Islands, Southern Indian Ocean
}

\author{
Paco Bustamante, Yves Cherel, Florence Caurant, Pierre Miramand
}

\section{To cite this version:}

Paco Bustamante, Yves Cherel, Florence Caurant, Pierre Miramand. Cadmium, copper and zinc in octopuses from Kerguelen Islands, Southern Indian Ocean. Polar Biology, 1998, 19 (4), pp.264-271. $10.1007 / \mathrm{s} 003000050244$. hal-00186628

\section{HAL Id: hal-00186628 \\ https://hal.science/hal-00186628}

Submitted on 10 Nov 2007

HAL is a multi-disciplinary open access archive for the deposit and dissemination of scientific research documents, whether they are published or not. The documents may come from teaching and research institutions in France or abroad, or from public or private research centers.
L'archive ouverte pluridisciplinaire HAL, est destinée au dépôt et à la diffusion de documents scientifiques de niveau recherche, publiés ou non, émanant des établissements d'enseignement et de recherche français ou étrangers, des laboratoires publics ou privés. 


\title{
Cadmium, copper and zinc in octopuses from Kerguelen Islands, Southern
}

\section{Indian Ocean}

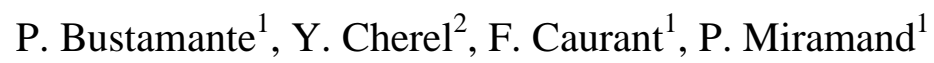

${ }^{1}$ Laboratoire de Biologie et Biochimie Marines, EA 1220, Université de La Rochelle, rue de Vaux de Foletier, 17026 La Rochelle Cedex, France

${ }^{2}$ Centre d'Etudes Biologiques de Chizé, UPR 4701 du Centre National de la Recherche Scientifique, F-79360 Villiers-en-Bois, France

\begin{abstract}
Concentrations of cadmium, copper and zinc were measured in 34 octopuses over a large range of size and weight caught in the Kerguelen shelf waters. Compared with levels normally encountered in European cephalopods, Cd concentrations in both species were very high: from 30.7 to 47.1 and from 27.3 to $54.4 \mu \mathrm{g} / \mathrm{g}$ dry weight in Graneledone sp. and Benthoctopus thielei, respectively; $\mathrm{Cu}$ concentrations were generally low while $\mathrm{Zn}$ concentrations exhibited similar levels. Distribution of $\mathrm{Cd}$ in tissues showed that the high levels of $\mathrm{Cd}$ in Kerguelen octopuses resulted from very high levels of the metal in the digestive gland (369 and $215 \mu \mathrm{g} / \mathrm{g}$ dry wt in Graneledone sp. and Benthoctopus thielei, respectively). Digestive gland accumulated about $90 \%$ of the total $\mathrm{Cd}$ in the whole animal. Due to the very high concentrations of $\mathrm{Cd}$ in the Kerguelen octopuses, we hypothesize that these species play an important role in the process of $\mathrm{Cd}$ transfer throughout the food chain to top vertebrate predators in this area.
\end{abstract}

KEY WORDS: Cephalopods . Octopus . Sub-Antarctic . Heavy metals . Cadmium . Digestive gland . Detoxification processes. 


\section{INTRODUCTION}

Recent studies have shown elevated concentrations of $\mathrm{Cd}$ in several marine invertebrates from Antarctic areas, mostly in crustaceans (Hennig et al. 1985; Mauri et al. 1990; Petri \& Zauke 1993; Zauke \& Petri 1993; Ahn et al. 1996; Bargagli et al. 1996). Data on Cd levels in mollusks from this area are few. Especially, there are no data available regarding cephalopods. First, cephalopods occupy a predominant niche in the trophic chains (Rodhouse \& Nigmatullin 1996), particularly in the Antarctic Polar Frontal Zone in the South Atlantic Ocean, where they, especially the ommastrephid Martialia hyadesi, occupy the ecological niche of epipelagic fish (Rodhouse \& White 1995). Cephalopods are predominant in the trophic system, because they are eaten by many oceanic animals like marine mammals (Clarke 1985; Clarke 1996), and seabirds (Croxall \& Prince 1996; Cherel \& Klages 1997). In the Southern Ocean, benthic octopuses were found in the food of Rockhopper and Gentoo penguins (Brown \& Klages 1987; Adams \& Klages 1989), royal albatrosses (Imber 1991) and Weddell seals (Clarke \& McLeod 1982). They were also reported as minor but regular prey of southern elephant seals (Rodhouse et al. 1992) and albatrosses (Cherel \& Klages 1997). In Kerguelen waters, octopuses are common items of black-browed albatrosses during the chick-rearing period (Y. Cherel and H. Weimerskirch, unpublished data) and they were found in the diet of gentoo penguins (Bost 1991). Second, some studies on elemental bioaccumulation show that cephalopods accumulate high levels of trace elements, particularly Cd and Cu (Ghiretti-Magaldi et al. 1958; Rocca 1969; Renzoni et al. 1973; Martin \& Flegal 1975; Smith et al. 1984; Miramand \& Guary 1980; Miramand \& Bentley 1992). Thus, cephalopods represent important species for studying the transfer of Cd into marine food webs in Antarctic and sub-Antarctic areas. 
This paper describes the bioaccumulation and tissue distribution of $\mathrm{Cd}, \mathrm{Cu}$ and $\mathrm{Zn}$ in two octopus species living in the Kerguelen shelf waters: Graneledone sp. and Benthoctopus thielei. The Kerguelen Islands constitute a small archipelago in the South Indian Ocean, at the Antarctic Polar Frontal Zone (Fig. 1), where release of heavy metals is presumably negligible or non-existent. Moreover, the Kerguelen Islands are of special interest because there is no information available on heavy metal levels in invertebrates from sub-Antarctic areas.

\section{MATERIALS AND METHODS}

Octopuses were collected from catches of a trawling fishery for Patagonian toothfish Dissostichus eleginoides in the upper slope $(400-600 \mathrm{~m})$ of the northern Kerguelen shelf, located between $47^{\circ} 00^{\prime}$ and $47^{\circ} 20^{\prime} \mathrm{S}$, and $69^{\circ} 00^{\prime}$ and $69^{\circ} 20^{\prime} \mathrm{E}$. They were immediately frozen aboard and kept at $-20^{\circ} \mathrm{C}$. Two groups of cephalopods were used: some were collected in February 1994, the others in May/June 1995. In order to calculate allometric equations between body mass, body length, hood, and crest lengths of beaks (Y. Cherel, unpublished data), the first group was thawed one time and re-frozen before heavy metal analysis. Thus, due to possible metal diffusion during a thawing/freezing cycle (Martin \& Flegal 1975), the distribution of heavy metals in various tissues was only measured in the latter group. Digestive gland, branchial hearts, gills, digestive tract, genital tract and ink sac were totally removed from the dissected individuals. In addition, pieces of mantle muscle and of the skin were sampled to determine metal concentrations. This implies that the remains of the animal were composed of arms, the rest of the mantle, muscle and skin. For all animals, stomach contents were removed before metal analysis. Our laboratory participate to European 
intercalibration exercises which allowed to quantify the internal analytical variability about $12.5 \%$.

For the nomenclature of the two octopus species commonly found in Kerguelen waters, i.e. Benthoctopus thielei and Graneledone sp. (a still undescribed species closely related to $G$. antarctica) we followed Nesis (1987). Seventeen individuals of each species were used: 11 females (mean wet wt $=123 \pm 89 \mathrm{~g}$ ) and 6 males (mean wet wt $=121 \pm 75 \mathrm{~g}$ ) of Benthoctopus thielei and 11 females (mean wet wt $=85 \pm 93 \mathrm{~g}$ ) and 6 males (mean wet wt $=$ $208 \pm 98 \mathrm{~g}$ ) of Graneledone sp. Each individual has been weighted and measured (mantle length, total length).

Tissue samples (whole individual regarding 1994 samples and the different organs regarding 1995 samples) were dried for several days at $80^{\circ} \mathrm{C}$ until constant weight. Two aliquots of approximately $300 \mathrm{mg}$ of each homogenised dry sample were digested with $4 \mathrm{ml}$ of $65 \%$ $\mathrm{HNO}_{3}$ and $1 \mathrm{ml}$ of $\mathrm{HClO}_{4} 70 \%$ during 24 hours at $80^{\circ} \mathrm{C}$. After evaporation, the residues were dissolved in nitric acid $0.3 \mathrm{~N}$. Blank were carried through the procedure in the same way as the sample. $\mathrm{Cu}$ and $\mathrm{Zn}$ were determined by flame and $\mathrm{Cd}$ by flameless atomic absorption spectrophotometry using a Varian spectrophotometer Vectra 250 Plus with Deuterium background correction.

All glassware and plastic was cleaned with $\mathrm{HNO}_{3} / \mathrm{HCl} 1 \mathrm{~N}$ and rinsed with deionized water. Reference material, Orchard-Leaves standard (NBS) and MA-A-2 fish-flesh standard (IAEA) were treated and analysed in the same way. The results for standards are shown in Table 1. All the results are given in micrograms of metal per gram of the dry weight tissue $(\mu \mathrm{g} / \mathrm{g}$ dry wt). For each element, the mean \pm standard deviation and the coefficient of variation are 
given. Distribution percentages of metals are given in percent of the total fresh weight of the individual.

\section{RESULTS}

Our sampling included males and females and represented a large range of size and weight: between $14 \mathrm{~g}$ and $279 \mathrm{~g}$ for Benthoctopus thielei and between $6 \mathrm{~g}$ and $343 \mathrm{~g}$ for Graneledone sp. Metal concentrations ( $\mu \mathrm{g} / \mathrm{g}$ dry wt) in Benthoctopus thielei and Graneledone sp. from the Kerguelen Island waters are reported in Table 2. In both species, $\mathrm{Cd}, \mathrm{Cu}$ and $\mathrm{Zn}$ were concentrated in similar amounts. Mean Cd concentrations were $39.1 \pm 5.3 \mu \mathrm{g} / \mathrm{g}$ in Graneledone sp. and $38.2 \pm 7.6 \mu \mathrm{g} / \mathrm{g}$ in Benthoctopus thielei. Mean Cu concentrations were $68 \pm 30 \mu \mathrm{g} / \mathrm{g}$ and $68 \pm 29 \mu \mathrm{g} / \mathrm{g}$ and corresponding $\mathrm{Zn}$ concentrations $131 \pm 19 \mu \mathrm{g} / \mathrm{g}$ in Graneledone sp. and $166 \pm 39 \mu \mathrm{g} / \mathrm{g}$ in Benthoctopus thielei.

For both species, heavy metal concentrations were similar in small and large individuals. The analytical results for males and females were compared. ANOVA test have shown no significant differences between metals concentrations by sex $(\mathrm{p}<0.05)$. For both elements, no correlation were found for Graneledone sp. while in Benthoctopus thielei, $\mathrm{Cd}$ and $\mathrm{Zn}$ were correlated positively $(\mathrm{p}<0.05)$ and $\mathrm{Cu}$ and $\mathrm{Zn}$ were correlated negatively $(\mathrm{p}<0.05)$. Figure 2 show relationships between metal concentrations and mantle length by sex. Correlation coefficients were significant in Graneledone sp. for $\mathrm{Cu}$ and $\mathrm{Zn}$ in females and in Benthoctopus thielei for $\mathrm{Cd}$ in males and $\mathrm{Zn}$ in females. The coefficients of variation $(\mathrm{CV})$ were less than $25 \%$ for $\mathrm{Cd}$ and $\mathrm{Zn}$, and near to $40 \%$ for $\mathrm{Cu}$ (Table 2).

The distribution of heavy metals in one individual of each species are reported in Table 3. Most of the Cd (91\% and $89 \%$, respectively in Graneledone sp. and Benthoctopus thielei) was accumulated in the digestive gland with concentrations as high as 369 and $245 \mu \mathrm{g} / \mathrm{g}$ in 
Graneledone sp. and Benthoctopus thielei, respectively. $\mathrm{Zn}$ concentration was higher in Benthoctopus thielei digestive gland $(416 \mu \mathrm{g} / \mathrm{g})$ and represented $53 \%$ of the total amount, whereas in Graneledone sp. it was close to the concentrations found in the other organs (102 $\mu \mathrm{g} / \mathrm{g}$ ), and represented only $16 \%$ of the total amount. In both species, the remains contained high percentages of Zn with $67 \%$ for Graneledone sp. and $44 \%$ for Benthoctopus thielei.

Total $\mathrm{Cu}$ concentrations (165 $\mu \mathrm{g} / \mathrm{g}$ for Graneledone sp. and $25 \mu \mathrm{g} / \mathrm{g}$ for Benthoctopus thielei) as well as distribution were quite different between both individuals. The digestive gland of Graneledone sp. exhibited high $\mathrm{Cu}$ concentration $(1092 \mu \mathrm{g} / \mathrm{g})$ and corresponded to the major site of $\mathrm{Cu}$ storage with $79 \%$ of the total body burden. In contrast, the digestive gland of Benthoctopus thielei contained only $25 \%$ of the total $\mathrm{Cu}$ body burden and displayed a very low concentration $(42 \mu \mathrm{g} / \mathrm{g})$.

\section{DISCUSSION}

\section{Metal Levels}

Despite the analysis of males and females over a large range of size and weight, the variability of the metal concentrations was relatively small. The most striking feature was the higher values for the coefficient of variation for $\mathrm{Cu}$ compared to that of $\mathrm{Cd}$ and $\mathrm{Zn}$.

The homogeneity of metal concentrations found in the 34 individuals was particularly remarkable. We hypothesise that the concentrations measured in this study were a relatively good representation of the concentrations encountered in specimens subject to similar ambient water composition and probably similar diets. Nevertheless, the coefficient of variation of $\mathrm{Cu}$ was particularly interesting. This coefficient was higher in both species sampled from the Kerguelen waters than in other octopuses species: $27 \%$ in Octopus 
vulgaris (Miramand and Guary 1980) and $11 \%$ for Eledone cirrhosa (Miramand and Bentley 1992). Moreover the $\mathrm{Cu}$ variability was higher than $\mathrm{Cd}$ variability. This was surprising when one considers that $\mathrm{Cu}$ and $\mathrm{Zn}$ (unlike $\mathrm{Cd}$ ) are essential elements which implies that they are maintained at a fairly constant concentration. The high $\mathrm{Cd}$ concentration might disrupt $\mathrm{Cu}$ homeostasis.

In order to compare the concentration of trace elements with other cephalopod species, Table 4 shows $\mathrm{Cd}, \mathrm{Cu}$ and $\mathrm{Zn}$ concentrations in the digestive gland and in whole individuals of cephalopods from the European waters where industrial releases of pollutants occur. In both species from Kerguelen waters, $\mathrm{Zn}$ concentrations were in the same range than those found in other species (Table 4).

In contrast, $\mathrm{Cd}$ and $\mathrm{Cu}$ concentrations found in octopuses caught from Kerguelen waters were noteworthy. $\mathrm{Cu}$ concentrations were low except for one individual for Graneledone sp. (165 $\mu \mathrm{g} / \mathrm{g}$ ) and two individuals of Benthoctopus thielei (114 and $149 \mu \mathrm{g} / \mathrm{g}$ ) (Table 2 and Table 4). Cd concentrations in both species were very high (Table 2). These concentrations in Kerguelen Islands octopuses were one order of magnitude greater than those found in others cephalopods (Table 4).

Such high Cd concentrations were unexpected for mollusks coming from a presumably unpolluted area far from any anthropogenic source of contaminants. Recently, Bargagli et al. (1996) have measured Cd concentrations in various organisms caught in Terra Nova Bay (Antarctica). All organisms collected in this area showed relatively elevated concentrations, but in most groups, concentrations were lower than $10 \mu \mathrm{g} / \mathrm{g}$ dry wt or close to $15 \mu \mathrm{g} / \mathrm{g}$ dry wt. Only some samples of the sponge Porifera exhibited higher Cd concentrations (i.e. 10-80 $\mu \mathrm{g} / \mathrm{g}$ dry wt). In Antarctic areas, such high Cd concentrations only occurred in the scallop Adamussium colbecki (Berkman \& Nigro 1992), and in some zooplanktonic crustaceans, 
particularly in the hyperiid amphipod Themisto gaudichaudii. These species accumulated Cd to levels similar or greater than Kerguelen octopuses (Hennig et al. 1985). Compared with Cd concentrations in other mollusk species, these concentrations were also remarkable. Thus, most of the mollusks species (bivalves and gastropods) caught in unpolluted areas contained Cd concentrations lower than $5 \mu \mathrm{g} / \mathrm{g}$ dry wt (Eisler 1981, Bryan 1984). Only some Pectinidae species which are well known for their ability to accumulate $\mathrm{Cd}$, exhibited concentrations nearer to those found in the Kerguelen octopuses (Bryan 1973; Berkman \& Nigro 1992; Francesconi et al. 1993). For comparison, Cd concentrations similar to those found in whole Kerguelen octopuses (excluding Pectinidae) have only encountered in filter-feeders caught in a Cd polluted area (Boutier \& Chiffoleau 1986).

The particular strong accumulation of $\mathrm{Cd}$ in octopuses from Kerguelen, an area without anthropogenic inputs of this metal, is difficult to explain. The Kerguelen Islands are located at the Antarctic Polar Frontal Zone (Fig. 1), and Cd enrichment in surface waters may occur due to upwelling of deep nutrient-rich waters. Unfortunately, we lack measurements of dissolved $\mathrm{Cd}$ in Kerguelen sea water and this hypothesis cannot be tested. Nevertheless, metal analyses of the stomach content of some Kerguelen octopuses showed elevated Cd concentrations greater than $30 \mu \mathrm{g} / \mathrm{g}$ dry wt (unpublished data). This suggests elevated $\mathrm{Cd}$ concentrations in octopus prey which could be an indicator of a $\mathrm{Cd}$ enrichment in Kerguelen waters or bottom fauna. In this context, food could be an important pathway of Cd uptake for Kerguelen Octopodidae. Octopus eat many prey species, mainly crustaceans, mollusks and fishes (Boyle 1990; McQuaid 1994; Laidig et al. 1995) but it has been impossible to determine clearly the diets of Kerguelen octopuses from stomach contents and no fish otoliths was found. The carnivorous diets of octopuses rely on the hypotheses of low supply of Cd by the soluble phase, unlike suspensivors species which filter important volumes to feed on 
micro-organisms. Moreover, gills in cephalopods shown low $\mathrm{Cd}$ concentrations and present less than $1 \%$ of the total Cd body burden (Table 3, Miramand \& Bentley 1992).

\section{Distribution of metals and implication in detoxification process}

The dissection of a single individual of Graneledone sp. and one individual of Benthoctopus thielei (Table 3) indicate that these Kerguelen octopuses exhibit a $\mathrm{Cd}$ distribution in tissue similar to that found in octopuses from the Mediterranean Sea (Miramand and Guary, 1980), or in the English Channel (Miramand \& Bentley 1992), with about $90 \%$ of the metal contained in the digestive gland. Digestive gland of Kerguelen octopuses contained very high concentrations (Table 3). In contrast, muscle concentrations are close to or slightly greater than those encountered in other octopus species $(0.1-0.5 \mu \mathrm{g} / \mathrm{g}$ dry wt) (Miramand \& Guary 1980; Miramand \& Bentley 1992; Barghigiani et al. 1993). Thus, the high concentrations measured in whole Kerguelen octopuses were due to the high concentrations in the digestive gland.

The high Cd concentrations in the digestive gland were greater than those usually found in others cephalopods (Table 4). Only two species caught in the Pacific Ocean exhibited similar or higher concentrations: Martin and Flegal (1975) found $287 \mu \mathrm{g} / \mathrm{g}$ dry wt in the squid liver of Ommastrephes bartrami and $782 \mu \mathrm{g} / \mathrm{g}$ dry wt in the squid liver of Symplectoteuthis oualaniensis. High concentrations of $\mathrm{Cd}$ in the digestive gland of cephalopods suggested that most of the detoxification processes occurred in this organ. However, studies on these mechanisms are scarce and concern only two squids species. Tanaka et al. (1983) and Finger and Smith (1987) have shown an association of Cd with high molecular weight material in the digestive gland of the squids Todarodes pacificus and Nototodarus gouldi. Nevertheless Cd detoxification processes in octopuses are not known and more studies are needed to 
clarify this mechanism. In this context, Kerguelen octopuses appear as good species for future investigations.

Branchial hearts of octopuses, which have polyhedral cells containing granules with brown pigments (adenochromes) rich in iron (Fox \& Updegraff 1943; Ghiretti-Magaldi et al. 1958; Nardi \& Steinberg 1974; Schipp \& Hevert 1978), are certainly also engaged in storage and detoxification processes for some trace elements such as cobalt, copper, vanadium (Ueda et al. 1979; Nakahara et al. 1979; Miramand \& Guary 1980), or transuranic elements (Guary et al. 1981; Miramand \& Guary 1981; Guary \& Fowler 1982). However, in European octopuses with relatively low $\mathrm{Cd}$ concentrations in whole tissues, branchial hearts (concentrations $<0.3$ $\pm 0.1 \mu \mathrm{g} / \mathrm{g}$ ) do not seem to be implicated in Cd detoxification processes (Miramand \& Guary 1980; Miramand \& Bentley 1992). In octopuses from Kerguelen, branchial hearts exhibited high Cd concentrations (Table 3). A possible hypothesis could be a is a threshold effect, that is, beyond a certain $\mathrm{Cd}$ concentration the digestive gland would not be sufficient for the entire detoxification processes and branchial hearts would then be used.

The ink sac of cephalopods contents melanin, a macromolecule with the ability to act as a cation-exchange resin (Larsson \& Tjalve 1978). It is known that tissues containing melanin pigments are often rich in some trace elements such as manganese, copper and zinc. The binding affinity of melanin towards certain metal ions has been investigated in some detail (Aime et al. 1989). The interaction is essentially electrostatic and its strength is therefore expected to be dependent on the charge to mass ratio of the metal ion. However, Sarzanini et al. (1992) have found in Sepia officinalis that the ability to concentrate metals by melanin is significantly lower than that observed for melanin sampled from other marine organisms, 
such as bivalves (Simkiss et al. 1982). The ink could be an excretion pathway for Cd while its missing in Kerguelen octopuses exclude Cd excretion by this way.

\section{Conclusion}

Due to the very high concentrations of cadmium in both Benthoctopus thielei and Graneledone sp., these cephalopods probably play an important role in the process of $\mathrm{Cd}$ transfer to top vertebrates predators in this region. Cd is well known for its accumulation in kidneys of vertebrates, where at high doses it causes renal diseases (Nicholson et al. 1983; Nogawa 1984; Lauwerys 1990). For human consumption, a "provisional tolerable weekly intake" of 400-500 $\mu \mathrm{g}$ Cd per person has been proposed by the World Health Organisation (1972). This approximates $1 \mu \mathrm{g} / \mathrm{kg}$ body weight for most individuals or $55-70 \mu \mathrm{g} / \mathrm{day}$. In Kerguelen, the daily consumption by marine predators of one small octopus (about $10 \mathrm{~g}$ wet weight) is sufficient to reach the equivalent of this dose. Thus, Kerguelen top predators, which have cephalopods in their diets, could achieve high levels of $\mathrm{Cd}$ in their tissues, like in the South Atlantic Ocean where cephalopod-eating albatrosses have high levels of cadmium in kidney and liver (Muirhead \& Furness 1988). In this context, research of Cd levels in tissues of top marine vertebrates from Kerguelen Islands, with particular attention to kidney, is of particular interest.

Acknowledgments. We thank Pascal Robidou for collecting octopuses on the French trawler 'Kerguelen de Trémarec' in February 1994, and Guy Duhamel for providing us with other specimens collected in May/June 1995. This work was supported financially by the Regional Council of Poitou-Charentes and Rhône-Poulenc, and by the Institut Français pour la Recherche et la Technologie Polaires and the Terres Australes et Antarctiques Françaises. 


\section{LITERATURE CITED}

Adams NJ, Klages NT (1989) Temporal variation in the diet of the gentoo penguin Pygoscelis papua at sub-Antarctic Marion Island. Colonial Waterbirds 12:30-36

Aime S, Botta M, Camurati I (1989) NMR studies of 1-dopa melanin-manganese (II) complex in water solution. J Inorg Biochem 35:1-9

Ahn IY, Lee SH, Kim KT, Shim JH, Kim DY (1996) Baseline heavy metal concentrations in the antarctic clam, Laternula elliptica in Maxwell Bay, King George Island, Antarctica. Mar Pollut Bull 32(8/9):592-598

Bargagli R, Nelli L, Ancora S, Focardi S (1996) Elevated cadmium accumulation in marine organisms from Terra Nova Bay (Antarctica). Polar Biol 16:513-520

Barghigiani C, D'Ulivo A, Zamboni R, Lampugnani L (1993) Interaction between selenium and cadmium in Eledone cirrhosa of the Northern Tyrrhenian Sea. Mar Pollut Bull 26 (4):212-216

Berkman PA, Nigro M (1992) Trace metal concentrations in scallops around Antartica: extending the Mussel Watch Programme to the Southern Ocean. Mar Pollut Bull 24 (6):322-323 
Bost CA (1991) Variation spatio-temporelle des ressources marines et stratégies adaptatives des oiseaux côtiers : le cas du Manchot papou (Psygoscelis papua). Unpublished thèse d'Université, Paris XI

Boutier B, Chiffoleau JF (1986) La contamination par le cadmium en Gironde et son extension sur le plateau continental. Rapport IFREMER n ${ }^{\circ}$ DERO, - 86.12-MR. 28 p

Boyle PR (1990) Prey handling and salivary secretions in octopuses. In: Barnes M and Gibson RN (eds) Trophic relationships in the marine environment. Proceedings of the 24th European Marine Biology Symposium, Aberdeen University Press, Aberdeen, p 541-552

Brown CR, Klages NTW (1987) Seasonal and annual variation in diets of macaroni (Eudyptes chrysolophus) and southern rockhopper (E. Chrysocome chrysocome) penguins at sub-Antarctic Marion Island. J Zool (Lond) 212:7-28

Bryan GW (1973) The occurrence and seasonal variation of trace metals in the scallops Pecten maximus (L.) and Chlamys opercularis (L.). J mar biol Ass UK 53:145-166

Bryan GW (1976) Heavy metal contamination in the sea, Chap 3. In: Johnston R (ed) Marine Pollution. Academic Press, London, p 185-302

Bryan GW (1984) Pollution due to heavy metals and their compounds. In: Kinne O (ed) Marine Ecology Vol 5 Part 3. Chichester, Wiley-Interscience, p 1289-1431 
Cherel Y, Klages NTW (1997) A review of the food of albatrosses. In: Robertson G and Gales R (eds) Albatrosses Biology and Conservation. Chipping Norton, Australia: Surrey Beatty \& Sons, p 113-136

Clarke MR (1985) Cephalopods in the diet of cetaceans and seals. Rapp Comm Int Mer Médit 29 (8):211-219

Clarke MR (1996) Cephalopods as prey. III. Cetaceans. Phil Trans R Soc Lond B 351:10531065

Clarke MR, MacLeod N (1982) Cephalopods remains in the stomachs of eight Weddell seals. Br Antarct Surv Bull 57: 33-40

Croxall JP, Prince PA (1996) Cephalopods as prey. I. Seabirds. Phil Trans R Soc Lond B $351: 1023-1043$

Eisler (1981) Trace metal concentrations in marine organisms. Pergamon Press, New York

Finger JM, Smith JD (1987) Molecular association of $\mathrm{Cu}, \mathrm{Zn}, \mathrm{Cd}$ and ${ }^{210} \mathrm{Po}$ in the digestive gland of the squid Nototodarus gouldi. Mar Biol 95:87-91

Francesconi KA, Moore EJ, Joll LM (1993) Cadmium in the saucer scallop, Amussium balloti, from western Australian waters: concentrations in adductor muscle and redistribution following frozen storage. Aust J Mar Fresh Res 44:787-797 
Fox DL, Updegraff DM (1943) Adenochrome a glandular pigment in the branchial hearts of the octopus. Archs Biochem 1:339-356

Ghiretti-Magaldi A, Giuditta A, Ghiretti F (1958) Pathways of terminal respiration in marine invertebrates. I. The respiratory system in cephalopods. J Cell Comp Physiol 52:389-429

Guary JC, Higgo JJW, Cherry RD, Heyraud M (1981) High concentrations of transuranic and natural radioactive elements in the branchial hearts of the cephalopods Octopus vulgaris. Mar Ecol Prog Ser 4:123-126

Guary JC, Fowler SC (1982) Experimental studies on the biokinetics of plutonium and americium in the cephalopod Octopus vulgaris. Mar Ecol Prog Ser 7:327-335

Hennig HFKO, Eagle GA, McQuaid CD, Rickett LH (1985) Metal concentrations in Antarctic zooplankton species. In: Siefried WR, Condy PR and Laws RM (eds) Antarctic Nutrient Cycles and Food Webs. Springer-Verlag Berlin, Heidelberg, p 656-661

Imber MJ (1991) Feeding ecology of Antarctic and sub-Antarctic Procellariiformes. Acta XX Congressus Internationalis Ornithologici, p 1402-1412

Koubbi P, Ibaez F, Duhamel G (1991) Environmental influences on spatio-temporal oceanic distribution of ichthyoplankton around the Kerguelen Islands (Southern Ocean). Mar Ecol Prog Ser 72:225-238 
Laidig TE, Adams PB, Baxter CH, Butler JL (1995) Feeding on euphausiids by Octopus rubescens. Calif Fish and Game 81 (2):77-79

Larsson B, Tjalve H (1978) Studies on the melanin-affinity of metal ions. Acta Physiol Scand $104: 479-484$

Lauwerys RR (1990) Cadmium. In: Toxicologie industrielle et intoxication professionnelle. Masson, Paris, p 136-149

Martin JH, Flegal AR (1975) High copper concentrations in squid livers in association with elevated levels of silver, cadmium, and zinc. Mar Biol 30:51-55

Mauri M, Orlando E, Nigro M, Regoli F (1990) Heavy metals in the Antarctic scallop Adamussium colbecki. Mar Ecol Prog Ser 67:27-33

McQuaid CD (1994) Feeding behaviour and selection of bivalve prey by Octopus vulgaris Cuvier. J Exp Mar Biol Ecol 177:187-202

Miramand P, Guary JC (1980) High concentrations of some heavy metals in tissues of the Mediterranean octopus. Bull Environ Contam Toxicol 24:783-788

Miramand P, Guary JC (1981) Association of americium-241 with adenochromes in the branchial hearts of the cephalopod Octopus vulgaris. Mar Ecol Prog Ser 4:127-129 
Miramand P, Bentley D (1992) Concentration and distribution of heavy metals in tissues of two cephalopods, Eledone cirrhosa and Sepia officinalis, from the French coast of the English Channel. Mar Biol 114:407-414

Muirhead SJ, Furness RW (1988) Heavy metal concentrations in the tissues of seabirds from Gough Island, South Atlantic Ocean. Mar Pollut Bull 19:278-283

Nakahara M, Koyanagi T, Ueda T, Shimizu C (1979) Peculiar accumulation of cobalt-60 by the branchial hearts of Octopus. Bull Jap Soc Scient Fish 45:539

Nardi G, Steinberg H (1974) Isolation and distribution of adenochrome(s) in Octopus vulgaris. Comp. Biochem. Physiol 48 B:453-461

Nesis KN (1987) Cephalopods of the world. Squids, Cuttlefishes, Octopuses, and Allies. TFH Publications, Neptune City

Nicholson JK, Kendall MD, Osborn D (1983) Cadmium and mercury nephrotoxicity. Nature 304(5927):633-635

Nogawa K (1984) Cadmium. In: Changing Metal Cycles and Human Health. Nriagu JO (ed), Springer-Verlag, Berlin, pp 275-284

Petri G, Zauke GP (1993) Trace metal in the crustaceans in the Antarctic Ocean. Ambio 22:529-536 
Renzoni A, Bacci E, Falciai L (1973) Mercury concentration in the water, sediments and fauna of an area of the Tyrrhenian coast. Revue int Océanogr Méd 31-32:17-45

Rocca E (1969) Copper distribution in Octopus vulgaris Lam. hepatopancreas. Comp Biochem Physiol 28:67-82

Rodhouse PG, Nigmatullin ChM (1996) Role as consummers. Phil Trans R Soc Lond B $351: 1003-1022$

Rodhouse PG, White MG (1995) Cephalopods occupy the ecological niche of epipelagic fish in the Antarctic Polar Front Zone. Bio Bull mar Biol Lab, Woods Hole 189:77-80

Rodhouse PG, Arnbom TR, Fedak MA, Yeatman J, Murray AWA (1992) Cephalopod prey of the southern elephant seal, Mirounga leonina. Can J Zool 70:1007-1015

Sarzanini C, Mentasti E, Abollino O, Fasano M, Aime S (1992) Metal content in Sepia officinalis melanin. Mar Chem 39:243-250

Schipp R, Hevert F (1978) Distribution of copper and iron in some central organs of Sepia officinalis (Cephalopoda). A comparative study by flamless atomic absorption and electron microscopy. Mar Biol 47:391-399

Simkiss K, Taylor M, Mason AZ (1982) Metal detoxification and bioaccumulation in molluscs. Mar Biol Lett 3:187-201 
Smith JD, Plues L, Heyraud M, Cherry RD (1984) Concentrations of the elements Ag, Al, $\mathrm{Ca}, \mathrm{Cd}, \mathrm{Cu}, \mathrm{Fe}, \mathrm{Mg}, \mathrm{Pb}$ and $\mathrm{Zn}$, and the radionuclides ${ }^{210} \mathrm{~Pb}$ and ${ }^{210} \mathrm{Po}$ in the digestive gland of the squid Nototodarus gouldi. Mar Environ Res 13:55-68

Tanaka T, Hayashi Y, Ishizawa M (1983) Subcellular distribution and binding of heavy metals in the untreated liver of the squid; comparison with data from the livers of cadmium and silver exposed rats. Experientia 39:746-748

Ueda T, Nakahara M, Ishii T, Suzuki Y, Suzuki H (1979) Amounts of trace elements in marine cephalopods. J Radiat Res 20:338-342

Zauke GP, Petri G, (1993) Metal concentrations in Antarctic crustacean: the problem of background levels In: Dallinger R and Rainbow PS (eds) Ecotoxicology of metals in Invertebrates. Lewis publishers, London, p 73-101 


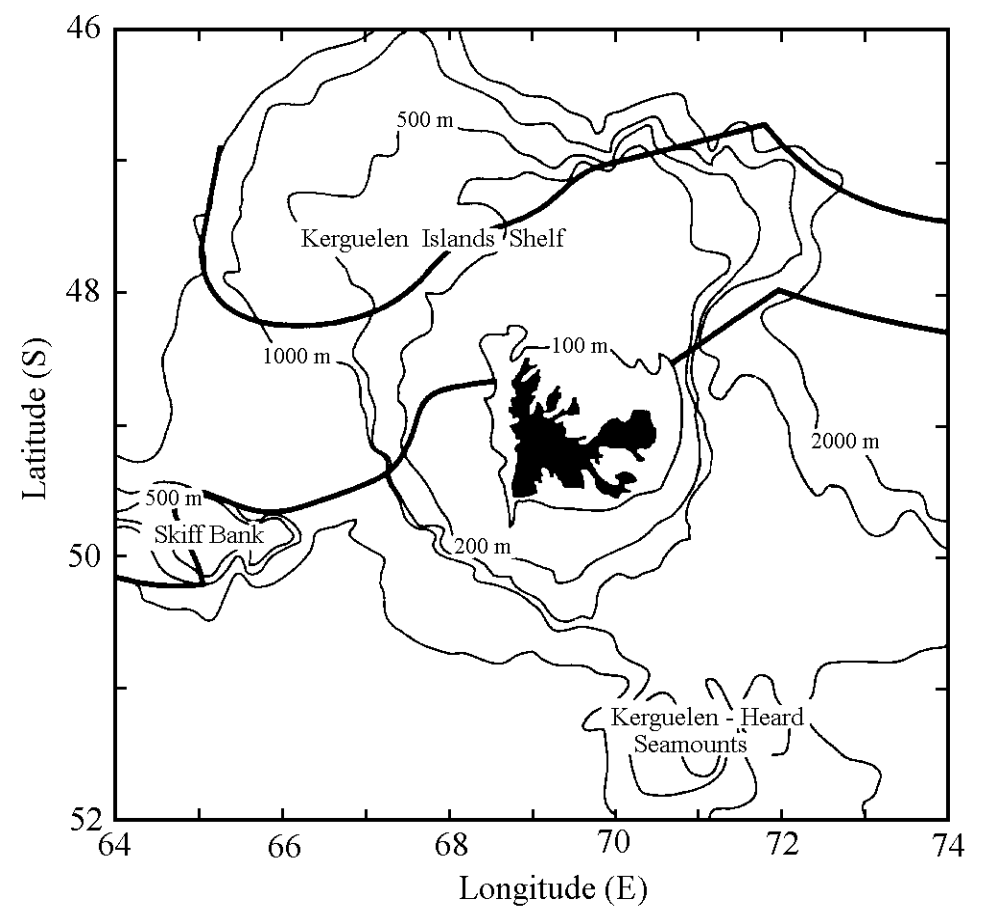

Fig 1 Location of the Kerguelen Archipelago and the southern and northern limits of the Antarctic Polar Front derived from joint FrenchSoviet oceanographic cruises in 1987 (Koubbi et al. 1991). 


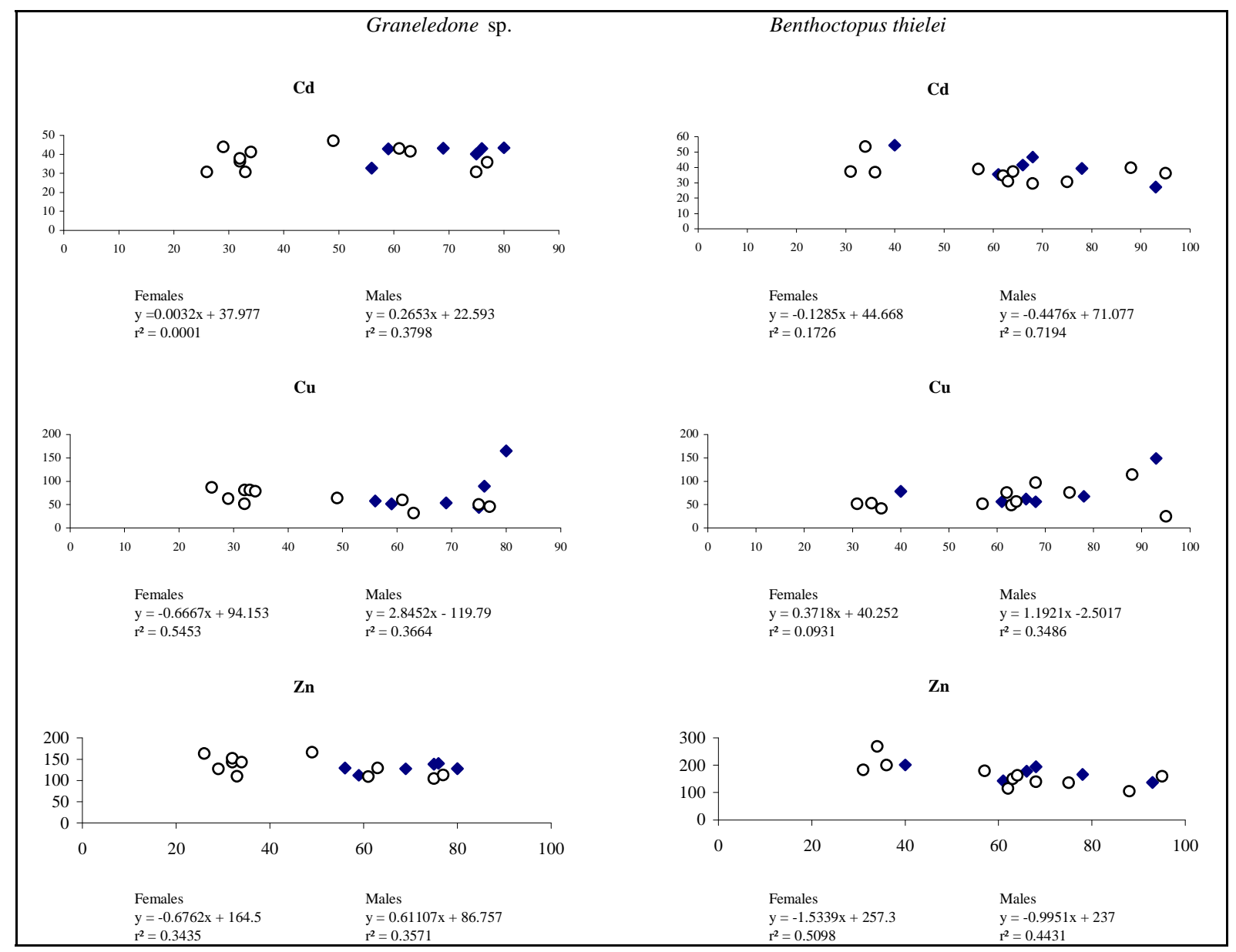

Fig. 2 Variations of metal concentrations ( $\mu \mathrm{g} / \mathrm{g}$ dry wt) in Kerguelen octopuses with mantle length (mm) by sex. $\diamond$ : males; ○: females 
Table 1 Concentrations ( $\mu \mathrm{g} / \mathrm{g}$ dry wt) of cadmium, copper and zinc in MA-A-2 fish flesh homogenate (mean \pm standard deviation) and Orchard Leaves (mean \pm confidence interval $95 \%$ ).

\begin{tabular}{lccc}
\hline Standards & $\mathrm{Cd}$ & $\mathrm{Cu}$ & $\mathrm{Zn}$ \\
\hline Orchard Leaves & & & \\
Present study & $0.13 \pm 0.03$ & $13 \pm 1$ & $25 \pm 2$ \\
Certified value & $0.11 \pm 0.02$ & $12 \pm 1$ & $25 \pm 3$ \\
MA-A-2 & & & \\
Present study & $0.064 \pm 0.001$ & $4.0 \pm 0.1$ & $34 \pm 2$ \\
Certified value & $0.066 \pm 0.004$ & $4.0 \pm 0.1$ & $33 \pm 1$ \\
\hline
\end{tabular}

\begin{tabular}{|c|c|c|c|c|c|c|c|}
\hline Species & Sample size & $\begin{array}{l}\text { Mantle length } \\
(\mathrm{mm})\end{array}$ & $\begin{array}{l}\text { Fresh weight } \\
(\mathrm{g})\end{array}$ & $\mathrm{Cd}$ & $\mathrm{Cu}$ & $\mathrm{Zn}$ & $\begin{array}{c}\text { Water content } \\
(\%)\end{array}$ \\
\hline \multicolumn{8}{|c|}{ Graneledone sp. } \\
\hline Males & 6 & & & & & & \\
\hline Mean & & 69 & 208 & 40.9 & 77 & 129 & 84 \\
\hline SD & & 10 & 97 & 4.2 & 46 & 10 & 1 \\
\hline $\mathrm{CV}(\%)$ & & 14 & 47 & 10 & 59 & 8 & 1 \\
\hline Range & & $56-80$ & $96-343$ & $32.8-43.5$ & $44-165$ & $112-140$ & $81-85$ \\
\hline Females & 11 & & & & & & \\
\hline Mean & & 46 & 85 & 38.1 & 63 & 133 & 84 \\
\hline SD & & 19 & 93 & 5.8 & 17 & 22 & 1 \\
\hline $\mathrm{CV}(\%)$ & & 42 & 110 & 15 & 28 & 17 & 1 \\
\hline Range & & $26-77$ & $6-232$ & $30.7-47.2$ & $32-87$ & $104-166$ & $83-86$ \\
\hline All specimens & 17 & & & & & & \\
\hline Mean & & 54 & 128 & 39.1 & 68 & 131 & 84 \\
\hline SD & & 20 & 110 & 5.3 & 30 & 19 & 1 \\
\hline $\mathrm{CV}(\%)$ & & 36 & 86 & 14 & 44 & 14 & 1 \\
\hline Range & & $26-80$ & $6-343$ & $30.7-47.2$ & $32-165$ & $104-166$ & $81-86$ \\
\hline \multicolumn{8}{|c|}{ Benthoctopus thielei } \\
\hline Males & 6 & & & & & & \\
\hline Mean & & 68 & 121 & 40.8 & 78 & 170 & 83 \\
\hline SD & & 18 & 75 & 9.3 & 36 & 26 & 2 \\
\hline $\mathrm{CV}(\%)$ & & 26 & 62 & 23 & 46 & 16 & 2 \\
\hline Range & & $40-93$ & $21-223$ & $27.3-54.4$ & $56-149$ & $137-201$ & $82-86$ \\
\hline Females & 11 & & & & & & \\
\hline Mean & & 61 & 123 & 36.8 & 63 & 163 & 82 \\
\hline SD & & 21 & 89 & 6.5 & 26 & 45 & 4 \\
\hline $\mathrm{CV}(\%)$ & & 34 & 72 & 18 & 41 & 28 & 5 \\
\hline Range & & $31-95$ & $14-279$ & $29.4-53.4$ & $25-114$ & $105-269$ & $76-89$ \\
\hline All specimens & 17 & & & & & & \\
\hline Mean & & 63 & 122 & 38.2 & 68 & 166 & 82 \\
\hline SD & & 20 & 82 & 7.6 & 29 & 39 & 3 \\
\hline $\mathrm{CV}(\%)$ & & 31 & 67 & 20 & 43 & 23 & 4 \\
\hline Range & & $31-95$ & $14-279$ & $27.3-54.4$ & $25-149$ & $105-269$ & $76-89$ \\
\hline
\end{tabular}


Table 3 Metal concentrations ( $\mu \mathrm{g} / \mathrm{g}$ dry wt) and percentage distribution (wet wt) in the organs of one male Graneledone sp. (fresh weight $=343 \mathrm{~g}$ ) and one female Benthoctopus thielei (fresh weight $=279 \mathrm{~g}$ ) caught in the Kerguelen shelf waters in May/June 1995. Skin and muscles are included in remainder.

\begin{tabular}{|c|c|c|c|c|c|c|c|}
\hline Organs & $\mathrm{Cd}$ & $\%$ & $\mathrm{Cu}$ & $\%$ & $\mathrm{Zn}$ & $\%$ & $\begin{array}{c}\text { Water content } \\
(\%)\end{array}$ \\
\hline \multicolumn{8}{|l|}{ Graneledone sp. } \\
\hline Digestive gland & 369 & 91.2 & 1092 & 79.9 & 102 & 15.8 & 68 \\
\hline Branchial hearts & 24.6 & 0.11 & 465 & 0.61 & 126 & 0.35 & 84 \\
\hline Gills & 22.6 & 0.52 & 530 & 3.59 & 98 & 1.41 & 84 \\
\hline Digestive tract & 90.5 & 1.96 & 354 & 2.27 & 92 & 1.25 & 85 \\
\hline Genital tract & 5.57 & 0.41 & 31 & 0.68 & 306 & 1.4 & 84 \\
\hline Remainder & 6.64 & 5.76 & 50 & 12.9 & 121 & 67.0 & 86 \\
\hline Skin & 1.94 & - & 67 & - & 121 & - & 90 \\
\hline Muscles & 0.37 & - & 15 & - & 113 & - & 87 \\
\hline Whole individual & 43.5 & 100 & 165 & 100 & 128 & 100 & 85 \\
\hline \multicolumn{8}{|l|}{ Benthoctopus thielei } \\
\hline Digestive gland & 215 & 88.6 & 42 & 24.8 & 416 & 52.6 & 69 \\
\hline Branchial hearts & 31.5 & 0.15 & 306 & 3.46 & 172 & 0.26 & 85 \\
\hline Gills & 49.1 & 0.89 & 168 & 7.07 & 147 & 0.82 & 84 \\
\hline Digestive tract & 85.1 & 1.30 & 35 & 1.24 & 202 & 0.95 & 86 \\
\hline Genital tract & 10.3 & 0.47 & 34 & 3.59 & 101 & 1.41 & 84 \\
\hline Remainder & 7.06 & 8.54 & 22 & 59.8 & 118 & 43.9 & 85 \\
\hline Skin & 0.81 & - & 18 & - & 95 & - & 90 \\
\hline Muscles & 0.21 & - & 3 & - & 138 & - & 82 \\
\hline Whole individual & 36.2 & 100 & 25 & 100 & 159 & 100 & 84 \\
\hline
\end{tabular}

